\title{
CONTEMPORARY INORGANIC THIN FILM PHOTOVOLTAIC MATERIALS AND TECHNOLOGIES
}

\author{
M. Topič* \\ University of Ljubljana, Faculty of Electrical Engineering, \\ Tržaška cesta 25, 1000 Ljubljana
}

\begin{abstract}
Summary: Inorganic thin film photovoltaic materials prove and even more promise that their small consumption and low cost are the drivers of high volume production of solar cells and photovoltaic modules. Representative types of contemporary inorganic thinfilm PV materials and technologies are reviewed and their state-of-the-art achievements and future trends presented.
\end{abstract}

Keywords: photovoltaics, solar cell, semiconductor, inorganic material, thin film.

\section{INTRODUCTION}

Inorganic thin-film photovoltaic (PV) materials and technologies have gained an important position in the photovoltaic industry and market. Small material consumption and low-temperature deposition processes applicable to large areas in either batch or roll-to-roll production lines make inorganic thin-film solar cells and modules competitive to crystalline silicon solar cells, regarding total costs and state-of-the-art performances [1]. Organic (or plastic) solar cell and dye-sensitized solar cells are part of the emerging PV technologies based on organic semiconductor materials. Organic solar photovoltaic cells consist of conductive organic polymers or small organic molecules for light absorption, charge separation and transport. Such active organic materials are sandwiched between the $\mathrm{PV}$-inactive layers that act as contacts, e.g. a transparent conductive oxide layer as the front contact. In this paper we will limit to and focus on inorganic thin film photovoltaic materials and their solar cell structures, the global market share of which in 2010 was around $15 \%(3.2 \mathrm{GW}$ out of $21 \mathrm{GW})$ and is forecasted to increase to $21 \%$ in 2012 [1].

Semiconductor materials used as active layers in inorganic thin film solar cells have amorphous or polycrystalline structure. Silicon-based representatives include hydrogenized amorphous, nanocrystalline or microcrystalline silicon (a-Si:H, nc-Si:H, $\mu \mathrm{c}-\mathrm{Si}: \mathrm{H})$; the main representative of chalcopyrites is polycrystalline $\mathrm{Cu}(\mathrm{In}, \mathrm{Ga})(\mathrm{Se}, \mathrm{S}) 2$ (CIGS), while for II-VI semiconductors it is polycrystalline cadmium telluride $(\mathrm{CdTe})$. Most of them exhibit higher absorption coefficient than crystalline silicon (c-Si)
(Fig. 1), thus efficient absorption of solar spectrum may occur in much thinner layers. Thin layers of the materials may be deposited at low temperatures (typically $200-500{ }^{\circ} \mathrm{C}$, in cases of a-Si:H even at room temperature) thus allowing the use of different rigid or flexible substrates such as glass, ceramic plates, plastic foils, metal foils, etc [2]. The main advantages of thin-film solar cells are low consumption of materials and energy during their fabrication, low-cost production. Drawbacks of these cells include lower conversion efficiencies [3] and in some cases, light-induced degradation of the materials [4]. For example, the best crystalline silicon cell achieved energy conversion efficiency of $25.0 \%$ under standard test conditions (STC) [5], while the record stabilized thin-film amorphous silicon solar cell exhibits $10.1 \%$ efficiency under STC [6]. In terms of the conversion efficiency, CdTe solar cells with the record efficiency of $16.7 \%$ [7] and CIGS solar cells with the record efficiency of $20.3 \%$ [8] are better representatives of the thin-film solar cells. In the following sections we will review individual types of inorganic thin-film PV materials and technologies and their state-of-the-art achievements.

\section{THIN FILM SILICON}

Apart from crystalline silicon, which is usually solidified in ingots and cut in wafers, thin film silicon is deposited from gaseous phase by Chemical Vapour Deposition (CVD) techniques in the form of hydrogenated amorphous, nanocrystalline or microcrystalline silicon thin films of different short- and long-range crystallographic order. 


\subsection{Hydrogenated Amorphous Silicon}

Amorphous silicon (a-Si) differs from crystalline silicon by the lack of long-range order in the crystallographic structure. Disordered silicon atoms in a-Si show many broken bonds that need to be passivated by hydrogen atoms to exhibit semiconductor properties. The content of bonded hydrogen can reach even $10 \%$ in the device-quality a-Si:H. The disorder leads to high optical absorption for the photon energies exceeding the optical band gap $(1,7 \mathrm{eV})$. However, the disorder causes high density of localized states (band-tail and mid-gap states) hampering the photogenerated charge carrier transport and enhancing the recombination losses. Due to Staebler-Wronski effect [4] the electrical properties of a-Si:H deteriorate under prolonged illumination since during the light soaking additional (metastable) defects are created and stabilized a$\mathrm{Si}: \mathrm{H}$ solar cells may lose up to $20 \%$ in conversion efficiency.

a-Si:H is deposited from radicals of silane $\left(\mathrm{SiH}_{4}\right)$ using Plasma Enhanced Chemical Vapour
Deposition (PE-CVD) at low temperatures of the substrate $\left(T<250{ }^{\circ} \mathrm{C}\right)$ [9]. Plasma is generated by capacitive coupling of electrodes in the vacuum chamber using a radio-frequency generator. Typically 13,56 MHz frequency (or higher) is used. PE-CVD enables homogeneous deposition of thin layers over large areas (Gen 8.5 chambers allow deposition over $2,2 \times 2,6 \mathrm{~m}^{2}$ ) boosting the throughput and decreasing the equipment cost. Alternative deposition techniques are Hot-Wire CVD (HWCVD) or Expanding Thermal Plasma CVD (ETPCVD) [9]. a-Si:H can be easily doped with phosphorous atoms by adding gas $\mathrm{PH}_{3}$ to silane $\left(\mathrm{SiH}_{4}\right)$ to deposit an n-doped layer or with boron atoms by adding gas $\mathrm{B}_{2} \mathrm{H}_{6}$ or $\mathrm{B}\left(\mathrm{CH}_{3}\right)_{3}$ to silane to deposit a pdoped layer. Usually, separate chambers are used for deposition of p-, i- and n- layers to prevent crosscontamination. In in-line deposition systems without a vacuum break the number of deposition chambers reflects the layer thickness ratios. Since the i-layer is the thickest, most chambers are used for sequential deposition of it.

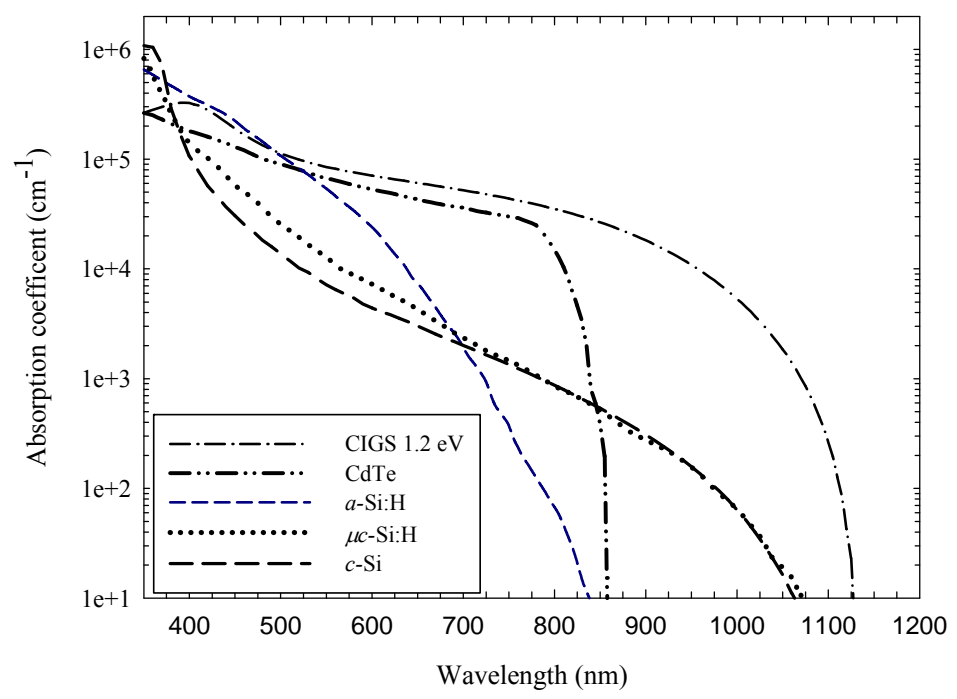

Figure 1. Wavelength-dependent absorption coefficients of selected inorganic PV materials.

The band gap of a-Si:H is not exactly defined. Mobility band gap $\left(E_{\mu}\right)$ and optical band gap $\left(E_{\text {opt }}\right)$ are used instead. $E_{\text {opt }}$ can be moderately varied by changing the hydrogen content (by changing hydrogen dilution during the deposition) and much more by alloying it with carbon (by adding methane $\left(\mathrm{CH}_{4}\right)$ to silane) or oxygen to enhance the $E_{\text {opt }}\left(\mathrm{a}-\mathrm{Si}_{1}\right.$ ${ }_{x} \mathrm{C}_{x}: \mathrm{H}$ or a- $\mathrm{Si}_{1-\mathrm{x}} \mathrm{O}_{\mathrm{x}}: \mathrm{H}$ ) or with germanium (by adding germane $\left(\mathrm{GeH}_{4}\right)$ to silane) to reduce the $E_{\text {opt }}\left(\mathrm{a}-\mathrm{Si}_{1-}\right.$ $\left.{ }_{x} \mathrm{Ge}_{x}: \mathrm{H}\right)$ depending on the fraction $x[10]$.

Creative efforts in material research, device physics and process engineering have led to stabili- zed efficiencies exceeding 10\%. a-Si:H-based solar cells are made in single-junction, tandem-junction or triple-junction structure. Unlike the c-Si pn or $\mathrm{np}$ single-junction structure, the a-Si:H single-junction cells have the pin structure (Fig. 2). An undoped (intrinsic) layer is placed between a very thin but highly doped $\mathrm{p}$ - and n-layer, so that the space charge region widens and the presence of built-in electric field $\left(E_{\mathrm{bi}}\right)$ extends across the whole pin structure. In this way, photogenerated carrier collection is aided by the $E_{\mathrm{bi}}$ that mitigates the low carrier lifetimes in a$\mathrm{Si}: \mathrm{H}$ and the collection is drift driven (in contrast to 
diffusion driven collection in c-Si cells). Biasing the a-Si:H cell with forward voltage lowers the electric field and leads to voltage-dependent photocurrent, resulting in a lower fill-factor and open-circuit voltage than anticipated.

Usually, single junction a-Si:H solar cells can be found in two configurations: superstrate $\mathrm{p}-\mathrm{i}-\mathrm{n}$ or substrate n-i-p. In case of the superstrate configuration (Fig. 2a) a transparent substrate covered with the transparent conductive oxide (TCO) as the front contact (FC) is located at the front side where incident light enters the cell. a-Si:H layers are deposited in a sequence of $\mathrm{p}$-doped (p-layer), undoped intrinsic (i-layer) and an n-doped (n-layer). Finally, back contact $(\mathrm{BC})$ is sputtered on top of the n-layer. In case of the substrate configuration (Fig. 2b) the deposition sequence is the opposite and front TCO layer is sputtered the last. In both configurations p-layer is located at the front part of the structure, where photogenerated carriers are predominantly generated, to enable shorter path for holes to reach the plus contact, since holes exhibit in a-Si:H typically 10 -times lower mobility than free electrons. To transmit as much incident light as possible to the i-layer, the optical band-gap of the p-layer is usually increased by carbon (or oxygen) alloying that builds an effective electric field for electrons in the vicinity of the $\mathrm{p} / \mathrm{i}$ interface that accelerates them in addition to the $E_{b i}$ across the p-i-n structure toward the minus (back) contact.

To mitigate the photocurrent dependency on forward voltage and also the light-induced degradation, the a-Si:H cells should be as thin as possible, while optically to absorb the whole incident light. This calls for enhanced light confinement in a-Si:H solar cells. One of the most efficient light trapping techniques is light scattering at rough (textured) interfaces in nanometer range. The ointroduction of light scattering may enhance the absorption in the single layer with refractive index $n$ up to factor $4 \times n^{2}$ [11]. Assuming an average value of $n=4$ for longer wavelengths in intrinsic a-Si:H material, the enhancement can reach the enviable number of 64 (in theory). In practice, the enhancement factors are still much below the ideal values, motivating several groups to investigate and optimize light scattering in a-Si:H as well as other thin-film silicon structures. Despite the complexity of scattering process in multilayer structures some optical models are capable of investigation and optimization of structures with rough and flat interfaces [SunShine [12], ASA [13], Cell [14]].

The optical optimisation is even more important for the tandem- and triple-junction cells, where the subcells are fabricated in a stacked structure and are electrically and optically connected in a series (Fig. 3). Due to a long-range disorder there is no need for lattice matching (in contrast to multijunction crystalline III-V solar cells). The fundamental concept underlying multijunction solar cells is multi band-gap approach that enables spectrum splitting. The top subcell absorbs the shorter wavelength part of the solar spectrum and transmits the longer wavelength part to the bottom subcell. Since the subcells are connected electrically in a series, the short-circuit currents of both subcells should be matched, while the open-circuits $\left(V_{\mathrm{oc}}\right)$ of the subcells will sum up. It is the higher $V_{\text {oc }}$ of the top cell that brings the enhancement of the conversion efficiency, since more incident solar power is converted into electricity. Until the late 1990s tandem and triplejunction cells were made of a-SiGe low band gap absorbers, but since the discovery of nanocrystalline or microcrystalline silicon material by the group of IMT Neuchatel headed by Prof. A. Shah [15] the tandem micromorph cell with a-Si:H wide bandgap top cell and $\mu \mathrm{c}-\mathrm{Si}: \mathrm{H}$ low band-gap bottom cell has been widely studied and optimized.

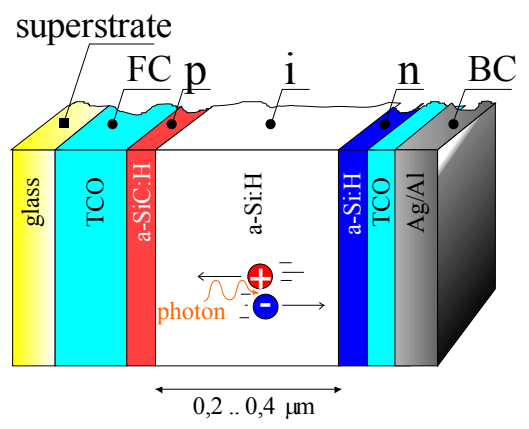

(a)

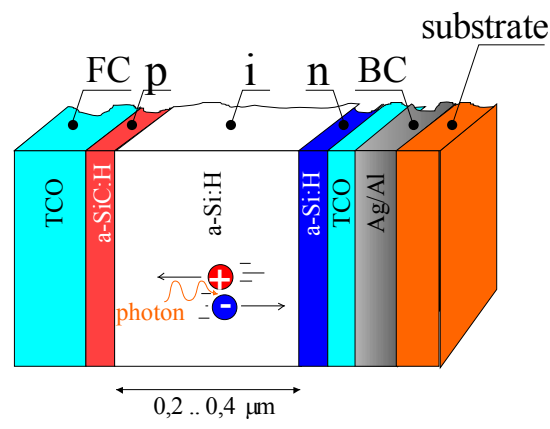

(b)

Figure 2. Schematic view of (a) superstrate p-i-n and (b) substrate n-i-p a-Si:H solar cell. 


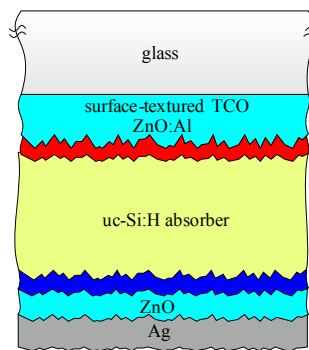

(a)

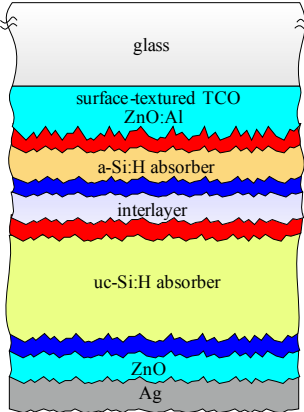

(b)

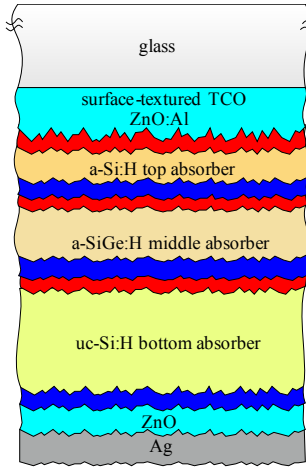

(c)

Figure 3. Schematic view of three advanced superstrate cell structures: (a) single-junction p-i-n $\mu c-S i: H$, (b) double-

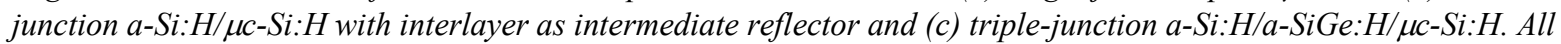
structures use random nanotextured front $\mathrm{TCO}\left(\mathrm{SnO}_{2}: \mathrm{F}, \mathrm{ZnO}: \mathrm{Al}\right.$ or $\left.\mathrm{ZnO}: \mathrm{B}\right)$ and a $\mathrm{ZnO} / \mathrm{Ag}$ back reflector and contact.

\subsection{Hydrogenated Nanocrystalline and Microcrystalline Silicon}

Hydrogenated nanocrystalline silicon (nc$\mathrm{Si}: \mathrm{H})$ and microcrystalline silicon ( $\mu \mathrm{c}-\mathrm{Si}: \mathrm{H})$ have been intensively studied in the past decades. At first they have been used as improved doped layers in a$\mathrm{Si}: \mathrm{H}$ solar cells due to better effective doping and lower activation energy rendering higher $E_{\mathrm{bi}}$ and $V_{\mathrm{oc}}$. In 1994 Meier et al [15] reported the fabrication of $\mu \mathrm{c}-\mathrm{Si}$ :H-based $\mathrm{p}-\mathrm{i}-\mathrm{n}$ solar cell using very high frequency PE-CVD that exhibits extended conversion efficiency in the longer wavelength range (up to $1100 \mathrm{~nm}$ ) rendering much higher short-circuits current. The major benefit of $\mu \mathrm{c}-\mathrm{Si}: \mathrm{H}$ solar cells was almost no degradation upon light soaking. However, the absorption coefficient of $\mu \mathrm{c}-\mathrm{Si}: \mathrm{H}$ is much lower (due to the indirect band gap of crystals) and thus the i-layer needs to be much thicker. This calls for higher deposition rates. The biggest progress was achieved in using VHF PE-CVD (40-100 MHz) combined with high-power and high-pressure regime [16]. Single junction $\mathrm{p}-\mathrm{i}-\mathrm{n} \mu \mathrm{c}-\mathrm{Si}: \mathrm{H}$ cells with over 9 $\%$ conversion efficiency have been fabricated at deposition rates of $2 \mathrm{~nm} / \mathrm{s}$ [17].

Another strategy is to use efficient light trapping by advanced photon management approaches. Efficient light scattering within the cell, which can boost the photocurrent generation, can be achieved by optimised random or periodic interface textures [18]. Recently, the role of metal nano-particles in thin-film solar cell structures has been also investigated in view of improved light trapping [19]. To minimise optical losses, antireflective coatings and advanced back reflectors are employed (photonic crystal structures [20] and diffusive dielectric materials [21]). In multi-bandgap multi-junction cells, light trapping needs to be accurately controlled, sin- ce the photogenerated current in subcells needs to be matched. For efficient spectrum harvesting, the concept of wavelength-selective intermediate reflectors has been investigated [22] and modification of doped layers to efficient intermediate reflectors has been demonstrated [23]. Research group of Oerlikon Solar has recently successfully launched the "think thin" concept where they succeeded in reducing the thickness of the whole micromorph ${ }^{\circledR}$ a-Si:H/ $/ \mu c-S i: H$ cell down to $1 \mu \mathrm{m}$ while maintaining the efficiency above $10 \%$. This approach is based on advanced light management that in production leads to less material and energy consumption and even more important to higher throughput and lower cost of equipment [http://www.oerlikon.com/solar/thinfab/].

\section{POLYCRYSTALLINE MATERIALS - CHALCOPYRITES, KESTERITES, CdTe}

\subsection{Copper Indium Selenide, its alloys and related chalcopyrites and kesterides}

$\mathrm{CuInSe}_{2}$ (CIS) belongs to selenide minerals and exhibits a chalcopyrite structure with a tetragonal unit cell. $\mathrm{CuInSe} \mathrm{S}_{2}$ can be arbitrary alloyed with $\mathrm{CuGaSe}{ }_{2}$ forming $\mathrm{Cu}\left(\mathrm{In}_{1-x}, \mathrm{Ga}_{x}\right) \mathrm{Se}_{2}$. Alloying enables modification of the energy bandgap $\left(E_{\mathrm{g}}\right)$ from 1.04 $\mathrm{eV}$ (without Ga, $x=0$ ) to $1.68 \mathrm{eV}$ (without In, $x=1$ ) following the empirical formula [24]:

$E_{\mathrm{g}}=1,04 \mathrm{eV}+0,39 \mathrm{eV} \times x+0,26 \times x^{2}$

A remarkable property of CIGS layers is their insensitivity to morphology and size of grains that indicates no significant recombination loss at grain boundaries. This applies to for grains of half micron diameter or larger. It is still not clarified whether this is due to inherent passivation $(\mathrm{Na}$ or $\mathrm{O})$ or $\mathrm{Cu}$ 
vacancies at the grain surfaces cause valance band offset [25]. The microstructure of $\mathrm{Cu}\left(\mathrm{In}_{1-x}, \mathrm{Ga}_{x}\right) \mathrm{Se}_{2}$ is influenced by substrate and the presence of $\mathrm{Na}$ (larger CIGS grains and preferred orientation of $<112>$ ).

A variety of deposition methods (evaporation, reactive sputtering, closed-space sublimation, chemical bath deposition, spray pirolysis) has been successfully applied to prepare $\mathrm{Cu}\left(\mathrm{In}_{1-x}, \mathrm{Ga}_{x}\right) \mathrm{Se}_{2}$ thin films. On the one hand physical vapour deposition in one step - elemental co-evaporation of $\mathrm{Cu}, \mathrm{In}, \mathrm{Ga}$ and $\mathrm{Se}$ to a heated substrate $\left(450-600{ }^{\circ} \mathrm{C}\right)$ delivers best device-quality films. On the other, a two-step deposition process that consists of low-cost and lowtemperature deposition of metal layers (cosputtering, electrodeposition, ink or spray techniques) followed by the annealing step in $\mathrm{H}_{2} \mathrm{Se}$ atmosphere has been successfully used in commercial manufacturing. To shorten the two-step approach a rapid thermal annealing in the second phase is usually applied. The thin films (typically from 1 to 2 $\mu \mathrm{m}$ thick) are polycrystalline and p-type semiconductor.

A typical CIGS solar cell is shown in Fig. 4a. The best ohmic contact to $\mathrm{Cu}(\mathrm{In}, \mathrm{Ga}) \mathrm{Se}_{2}$ is formed with Molibdenum on soda-line glass. The absorber $\mathrm{Cu}\left(\mathrm{In}_{1-x}, \mathrm{Ga}_{x}\right) \mathrm{Se}_{2}$ layer forms a heterojunction with a thin CdS layer that is n-type with a much higher bandgap. The growth of CdS thin films by chemical

bath deposition (CBD) allows ion-by-ion growing, resulting in a dense homogeneous film of CdS with crystallites in the ten nanometer range. During the $\mathrm{CdS}$ deposition, the surface of $\mathrm{Cu}(\mathrm{In}, \mathrm{Ga}) \mathrm{Se}_{2}$ grains is exposed to chemical etching by ammonia and intermixing of Se and $\mathrm{S}$ on both sides of the heterointerface may takes place, resulting in high quality $\mathrm{np}$ heterojunction and consequently solar cell. Although the Cd content in CIGS solar cells is low, regulation of $\mathrm{Cd}$ usage in electronic equipment and even more the concern about investors' attitude toward $\mathrm{Cd}$ has initiated development of $\mathrm{Cd}$-free $\mathrm{n}$ type buffer layers, in particularly the ones with a higher band-gap than 2,4 eV. Numerous wide-gap materials and deposition methods (CBD, atomic layer deposition, metal-organic CVD) have been investigated and the most promising buffer layers are $\mathrm{Zn}(\mathrm{S}, \mathrm{O}, \mathrm{OH})$ or $\mathrm{Zn}(\mathrm{Se}, \mathrm{O}, \mathrm{OH}), \mathrm{In}(\mathrm{OH}, \mathrm{S}), \mathrm{In}_{2} \mathrm{~S}_{3}$. To protect the buffer layer from harsh conditions during sputtering of $\mathrm{ZnO}: \mathrm{Al}$ a high-resistive undoped $\mathrm{ZnO}$ layer is deposited. It also mitigates the effect of inhomogeneities (e.g. weak-diode microcells) on overall performance [26].

A band diagram of $\mathrm{ZnO} / \mathrm{CdS} / \mathrm{Cu}(\mathrm{In}, \mathrm{Ga}) \mathrm{Se}_{2}$ is shown in Fig. $4 b$. The conduction band offset $\left(\Delta \mathrm{E}_{\mathrm{c}}\right)$ at the $\mathrm{CdS} / \mathrm{Cu}(\mathrm{In}, \mathrm{Ga}) \mathrm{Se}_{2}$ interface causes the type inversion and the buried np junction with space charge region that is shifted toward the back.

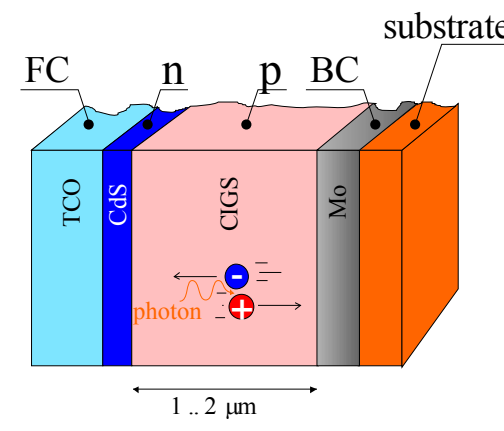

(a)

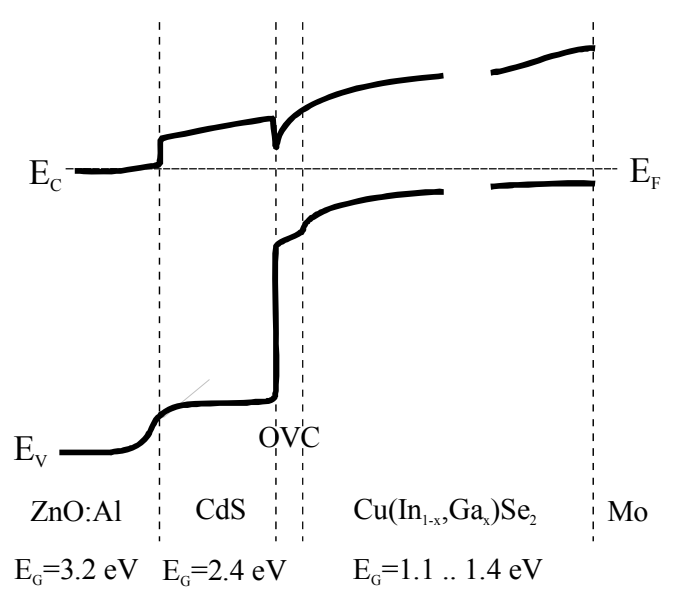

(b)

Figure 4. Schematic view of (a) substrate heterojunction np CdS/CIGS solar cell and (b) band-diagram of $\mathrm{ZnO} / \mathrm{CdS} / \mathrm{CIGS}$ structure.

Soda-lime glass is a common substrate material, but recently A. Tiwari with co-workers has made a remarkable progress on flexible substrates with cell efficiencies under STC of $18.7 \%$ for polymer foil and above $17,7 \%$ for steel foil substrate [27].

Band-gap grading in $\mathrm{Cu}(\mathrm{In}, \mathrm{Ga}) \mathrm{Se}_{2}$ solar cells can be achieved by a non-uniform $\mathrm{Ga} / \mathrm{In}$ ratio thro- ughout the film thickness. Numerical modeling tools have been used to clarify the best band-gap engineering approach and quantify the benefits of band-gap grading [28]. M. Gloecker [29] concluded that in standard thickness CIGS cells the benefit is smaller than commonly believed, while thin-absorber cells derive more substantial benefit. 
In respect to primary material supply for large-scale production of CIGS solar cells, the potential bottleneck is the In supply. This limiting factor can be mitigated by thinner CIGS cells or by Indiumfree alloys of which kesterite family of materials (composed of $\mathrm{Cu}, \mathrm{Zn}, \mathrm{Sn}$ and $\mathrm{Se}$ or $\mathrm{S}$, acronym CZTSS) is the most promising and record CZTSS cells have already exceeded efficiencies of $9.5 \%$ [30].

Recently the first gigawatt CIGS production plant has been put in operation by Frontier Solar [31]. The world's largest CIS PV production plant came on line in February, 2011. The Kunitomi Plant with 750 employees has fully-automated production lines inside the building area of $158,000 \mathrm{~m}^{2}$. Their mass-production thin-film CIGS PV modules are $\mathrm{Cd}$-free and $\mathrm{Pb}$-free (RoHS compliant) and exhibit STC efficiency from $11.4 \%$ to $12.6 \%$ (in 2011).

\subsection{Cadmium Telluride}

Cadmium Telluride (CdTe) is unique among II-VI compounds in that it exhibits the lowest melting temperature $(1365 \mathrm{~K})$, highest average atomic number, and largest lattice constant $(0,647 \mathrm{~nm})$. Electronically, CdTe exhibits amphoteric semiconducting behaviour, making it possible to dope both intrinsically and extrinsically (by impurities) to n- or p-type semiconductor. CdTe is a direct band gap of $1.5 \mathrm{eV}$ at $300 \mathrm{~K}$ with a weak temperature coefficient of about $-0.4 \mathrm{eV} / \mathrm{K}$.

Native defects and impurities (substitutional or interstitial) in CdTe produce localized shallow or deep trap states within the band gap and hence change the electronic properties. Acceptor doping (ptype) is less efficient than the donor doping (n-type). The desired electronic properties of polycrystalline CdTe are obtained by activation treatments $\left(\mathrm{CdCl}_{2}\right.$, $\mathrm{O}_{2}$ and $\mathrm{Cu}$ ) that activate or passivate native defects and help in rearrangement to larger grains that suppress recombination and thus improve effective carrier lifetime.

Similarly to CIGS, a variety of deposition methods have been successfully applied to deposit CdTe thin films [32]. The most successful among them so far are Close Space Sublimation, Physical Vapour Deposition and Vapour Transport Deposition, where condensation of $\mathrm{Cd}$ and $\mathrm{Te}_{2}$ vapours on a heated substrate takes place. The electrodeposition method is among the most successful and low-cost..

A typical CdTe solar cell is deposited on glass $/ \mathrm{SnO}_{2}: \mathrm{F}$ superstrate (schematically shown in Fig. 6.a), although recently also $\mathrm{ZnO}: \mathrm{Al} / \mathrm{i}-\mathrm{ZnO}$ has been successfully used as the front contact [33]. Significant progress has been achieved in substrate configuration using metal foils [27]. A good ohmic back contact to the CdTe absorber is not straightforward, but requires a $\mathrm{CdCl}_{2}$ activation treatment at elevated temperatures (around $400{ }^{\circ} \mathrm{C}$ ) that forms Telluriumrich $\mathrm{p}+$-type grain surface. The post-deposition $\mathrm{CdCl}_{2}$ treatment is not only beneficial to the back surface, but also reduces the CdTe cross-grain sheet resistance and results in reduced donor defect density in CdTe and $\mathrm{CdS} / \mathrm{CdTe}$ interdiffusion thus remarkably impacting improved photocurrent and uniformity [34]. The Te-rich surface is covered by a $\mathrm{Cu}-\mathrm{Au}$ or graphite electrical back contact (a conductive buffer layer to mitigate the Schottky barrier and undesirable band bending at the back, see Fig. 6.b) [35]. The back-contact barrier is essentially a second diode with opposite polarity to the np heterojunction. Its height can be reduced by addition of $\mathrm{Cu}$, although high bulk-diffusion coefficient for $\mathrm{Cu}$ in CdTe may initiate potential stability issues in hot climate locations [36]. The barrier depletion width depends on the doping level of the CdTe. For a higher doping, the depletion width is small and it does not affect the band bending across the absorber, but usually lower doping needs to be compensated by a thicker CdTe absorber.

There is a significant difference in performance between today's highest efficiency of thin-film polycrystalline CdTe solar cells and single-crystal cells of comparable band gap (GaAs). The opencircuit voltage (more than $200 \mathrm{mV}$ ) presents the largest contribution to this difference.. CdTe opencircuit voltage and fill-factor are currently limited by low recombination lifetime (near $1 \mathrm{~ns}$ ), low hole density (near $10^{14} \mathrm{~cm}^{-3}$ ), and the back-contact barrier. Two different strategies for improving voltage and performance have been suggested [37]. One of them is back surface field by increased doping toward the back contact and another one is the incorporation of a conduction-band energy barrier at the back surface of the solar cell that acts as an electron reflector, which can reduce the recombination due to the reduced electron flow to the back surface. The investigation has shown that the expandedband-gap layer is the most efficient and practical mechanism for an electron reflector [38], however band-gap engineering in CdTe is much more difficult to implement than in CIGS solar cells and further R\&D efforts are needed.

The CdTe solar cell level research has been translated to high-volume and fast-growing massproduction of CdTe PV modules. In 2009, First Solar Inc. became the first PV module manufacturing company to lower its manufacturing cost to $\$ 1 / \mathrm{W}$ [39], which was a significant milestone in the race for PV cost competitiveness. At the end of 2009, First Solar had surpassed an annual production of $1 \mathrm{GW}$ and has been the largest thin film PV 
module manufacturer in the world since 2007. At the end of 2010, their annual production capacity (facto- ries in USA, Germany and Malaysia) was $1.5 \mathrm{GW}$ [40].

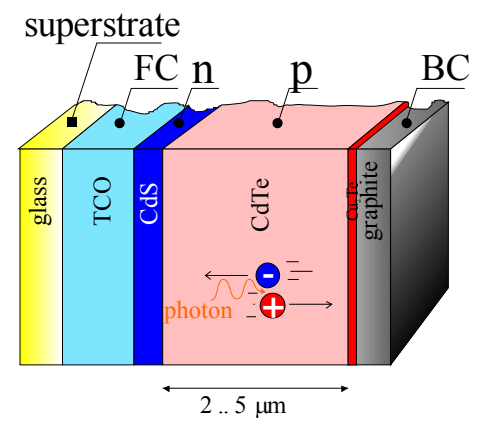

(a)

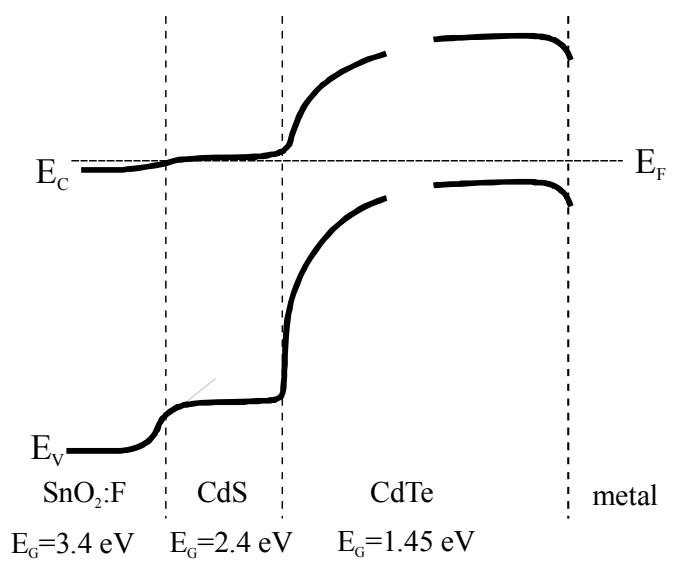

(b)

Figure 5. Schematic view of (a) superstrate heterojunction $n p$ CdS/CdTe solar cell and (b) band-diagram of $\mathrm{ZnO} / \mathrm{CdS} / \mathrm{CdTe} /$ metal structure.

\section{CONCLUSION}

Inorganic thin film photovoltaic materials have been reviewed. A variety of deposition techniques that allow deposition of inorganic thin films with small energy footprint and contribute to the promising low-cost photovoltaics as been presented. Small material consumption and high volume production of solar cells and photovoltaic modules make them competitive and sustainable contemporary PV technologies. A-Si:H, nc-Si:H and $\mu \mathrm{c}-\mathrm{Si}: \mathrm{H}$ are at the forefront among the thin film silicon materials and CIGS and CdTe at the forefront of polycrystalline candidates whose state-of-the-art performance, bottlenecks and future challenges have been presented.

\section{ACKNOWLEDGEMENTS}

The author is grateful for the funding by the Slovenian Research Agency (P2-0197). The author would like to thank J. Krč, F. Smole, J.R. Sites, and M. Zeman for fruitful discussions.

\section{REFERENCES}

[1] A. Jäger-Waldau, PV Status Report 2011, Luxembourg: Office for Official Publications of the European Union, Brussels 2011. 126 pages. [Ebook] Available: http://re.jrc.ec.europa.eu/refsys/.
[2] Y. Hishikawa, K.Tabuchi, S.Kato, A. Takano, T. Sasaki, M. Tanda, S. Saito, H. Sato, S. Fujikake, T. Yoshida and H. Sakai, A new structure a-Si solar cell with plastic film substrate, Proc. of first WCPEC, Hawaii, USA, 1994, 441.

[3] M. A. Green, K. Emery, Y. Hishikawa and W. Warta, E. D. Dunlop, Solar cell efficiency tables (version 38), Prog. Photovolt: Res. Appl. 19 (2011) 565-572.

[4] D. L. Staebler and C. R. Wronski, Reversible conductivity changes in discharge-produced amorphous silicon, Appl. Phys. Lett., 31 (1977) 292-294.

[5] J. Zhao, A. Wang, M. A. Green, F. Ferrazza, $19.8 \%$ efficient "honeycomb" textured multicrystalline and $24.4 \%$ monocrystalline silicon solar cells, Applied Physics Letters, 73 (1998) 1991-1993.

[6] S. Benagli, D. Borrello, E. Vallat-Sauvain, J. Meier, U. Kroll, J. Hotzel, J. Spitznagel, J. Steinhauser, L. Castens, Y. Djeridane, High-efficiency Amorphous Silicon Devices on LPCVD-ZnO TCO Prepared in Industrial KAI-M R\&D Reactor, 24th European Photovoltaic Solar Energy Conference, Hamburg, September 2009, 344-349.

[7] X. Wu, J.C. Keane, R.G. Dhere, C. DeHart, A. Duda, T. A. Gessert, S. Asher, D. H. Levi, P. Sheldon, $16.5 \%$-efficient CdS/CdTepolycrystalline thin-film solar cell, Proceeding of 17th European Photovoltaic Solar Energy Conference, Munich, Germany, 2001, 995-1000.

[8] P. Jackson, D. Hariskos, E. Lotter, S. Paetel, R. Wuerz, R. Menner, W. Wischmann, M. 
Powalla, New world record efficiency for $\mathrm{Cu}(\mathrm{In}, \mathrm{Ga}) \mathrm{Se}_{2}$ thin-film solar cells beyond 20\%, Progress In Photovoltaics: Research and Applications, 2011; published online DOI: 10.1002/pip.1078.

[9] R. E. I. Schropp, M. Zeman, Amorphous and microcrystalline silicon solar cells: Modeling, Materials and Device Technology, Kluwer Academic Publisher, 1998.

[10] A.S. Ferlauto et al., Modeling the dielectric functions of silicon-based films in the amorphous, nanocrystalline and microcrystalline regimes, Journal of Non-Crystalline Solids, 266-269 (2000) 269-273.

[11] M.A. Green, Lambertian light trapping in textured solar cells and light-emitting diodes: analytical solutions, Progress in Photovoltaics: Research and Applications, 10 (2002) 235-241.

[12] J. Krč, F. Smole, M. TOPIČ, Analysis of light scattering in amorphous Si:H solar cells by a one-dimensional semi-coherent optical model, Progress in photovoltaics: Research and Applications, 11 (2003) 15-26.

[13] M. Zeman, R.A.C.M.M. van Swaaij, J.W. Metselaar, R.E.I. Schropp, Optical modeling of aSi:H solar cells with rough interfaces: Effect of back contact and interface roughness, Journal of Applied Physics 88 (2000) 6436-6442.

[14] J. Špringer, A. Poruba, M. Vaneček, S. Fay, L. Feitknecht, N. Wyrsch, J. Meier, A. Shah, T. Repmann, O. Kluth, H. Stiebig, B. Rech, Proceedings of the $17^{\text {th }}$ European Photovoltaic Solar Energy Conference, Munich, Germany, 2001, 2830-2833.

[15] J. Meier, R. Fluckinger, H. Keppner, $A$. Shah, Complete microcrystalline p-i-n solar cellCrystalline or amorphous cell behavior?, Applied Physics Letters, 65 (1994) 860-862.

[16] A. Smets, T. Matsui, M. Kondo, Highrate deposition of microcrystalline silicon $p-i-n$ solar cells in the high pressure depletion regime, Journal of Applied Physics 104 (2008) 034508.

[17] T. Matsui, A. Matsuda, M. Kondo, Solar Energy Materials and Solar Cells 90 (2006) 319993204.

[18] M. Zeman, J. Krč, Optical and electrical modeling of thin-film silicon solar cells, J. Mater. Res., 23 (2008) 889-898.

[19] M. Schmid, R. Klenk, M. Ch. LuxSteiner, M. Topič, J. Krč, Modeling plasmonic scattering combined with thin-film optics, Nanotechnology 22 (2011) 025204.

[20] J. Krč, M. Zeman, L. Luxembourg, M. Topic, Appl. Phys. Lett. 94 (2009) 153501.

[21] B. Lipovšek, J. Krč, O. Isabella, M. Zeman, M. Topič, Modeling and optimization of white paint back reflectors for thin-film silicon solar cells, J. Appl. Phys. 108 (2010) 103115.

[22] J. Krč, B. Lipovšek, M.Topič, Light Management in Thin-Film Solar Cell, chapter 4 in book A.B. Cristóbal López et al. (Eds.), Next Generation of Photovoltaics, Springer Series in Optical Sciences 165, DOI 10.1007/978-3-642-23369-2 4.

[23] P. Cuony, M. Marending, D. T. L. Alexander, M. Boccard, G. Bugnon, M. Despeisse, and C. Ballif, Mixed-phase p-type silicon oxide containing silicon nanocrystals and its role in thin-film silicon solar cells, Appl. Phys. Lett. 97 (2010) 213502.

[24] S. Wei, A. Zunger, Calculated Natural Bond Offsets of all II-VI and III-V Semiconductors: Chemical Trends and the Role of Cation d Orbitals, Appl. Phys. Lett 72 (1998) 2011-2013.

[25] U. Rau, K. Taretto, S. Siebentritt, Grain Boundaries in $\mathrm{Cu}(\mathrm{In}, \mathrm{Ga})(\mathrm{Se}, \mathrm{S}) 2$ Thin-film Solar Cells, Appl. Phys. A 96 (2009) 221-234.

[26] U. Rau, M. Schmidt, Electronic properties of $\mathrm{ZnO} / \mathrm{CdS} / \mathrm{Cu}(\mathrm{In}, \mathrm{Ga}) \mathrm{Se}_{2}$ solar cells - aspects of heterojunction formation, Thin Solid Films, 387 (2001) 141-146.

[27] A. N. Tiwari, Plenary talk at the 26-EUPVSEC, Hamburg 2011.

[28] M. Topič, F. Smole, J. Furlan, Band-gap engineering in $\mathrm{CdS} / \mathrm{Cu}(\mathrm{In}, \mathrm{Ga}) \mathrm{Se} 2$ solar cells, J. Appl. Phys. 79 (1996) 8537-8540.

[29] M. Gloeckler, J. R. Sites, Band-gap grading in $\mathrm{Cu}(\mathrm{In}, \mathrm{Ga}) \mathrm{Se}_{2}$ solar cells, Journal of Physics and Chemistry of Solids 66 (2005) 1891-1894.

[30] T. K. Todorov, K. B. Reuter, D. B. Mitzi, High-Efficiency Solar Cell with Earth-Abundant Liquid-Processed Absorber, Advanced Materials, 22 (2010) E156-E159.

fronti-

[31] http://www.solar-

er.com/GeneralPage/28/Kunitomi_Plant_Photo_Gallery/1 (accessed 24 Nov 2011)

[32] D. Bonnet, P. Meyers, J. Mater. Res. 10 (1998) 2740-2754.

[33] J. Perrenoud, J , L. Kranz, S. Buecheler, F. Pianezzi, A.N. Tiwari, Thin Solid Films 519 (2011) 7444-7448 doi: 10.1016/j.tsf.2010.12.234

[34] J. Hiltner, J.R.Sites Mat.Res.Soc. Proc. 668 (2001) H9.8.

[35] Enzenroth R. A.; Barth K. L.; Sampath W. S.; et al., Journal of Solar Energy Engineering Transactions of the ASME 131 (2009) 021012.

[36] Dobson KD; Visoly-Fisher I; Hodes G; et al., Stability of $C d T e / C d S$ thinfilm solar cells, Solar Energy Materials and Solar Cells 62 (2000) 295-325. 
[37] J.R. Sites, J. Pan, Strategies to increase CdTe solar-cell voltage, Thin Solid Films 515 (2007) 6099-6102.

[38] K.-J. Hsiao, J.R. Sites, Proc. 34th IEEE Photovoltaics Specialists Conf., Philadelphia (2009), pp. 001846-001850.
[39] A. Jäger-Waldau, PV Status Report 2010, Luxembourg: Office for Official Publications of the European Union, Brussels 2010. 121 pages. [Ebook] Available: http://re.jrc.ec.europa.eu/refsys/.

[40] First Solar Financial Report for Q3/2011. Available: http://finance.yahoo.com

gOP

\section{САВРЕМЕНИ НЕОРГАНСКИ ТАНКОСЛОЈНИ ФОТОНАПОНСКИ МАТЕРИЈАЛИ И ТЕХНОЛОГИЈЕ}

Сажетак: Неоргански танкослојни фотонапонски материјали доказују, и штавише, обећавају да ће њихова мала потрошња и ниска цијена бити покретач масовне производње соларних ћелија и фотонапонских модула. Приказане су типичне врсте савремених танкослојних фотонапонских материјала и технологија као и њихова најновија достигнућа и будући трендови.

Кључне ријечи: фотонапонски, соларна ћелија, полупроводник, неоргански материјал, танки слој.

$\cos 80$ 